\title{
TRANSFORMATION OF OIL PALM INDEPENDENT SMALLHOLDERS THROUGH MALAYSIAN SUSTAINABLE PALM OIL
}

\author{
ROSEARNIDA SENAWI*; NAZIRA KHABIBOR RAHMAN*; NURHANANI MANSOR* \\ and AINIE KUNTOM*
}

\begin{abstract}
Malaysian Sustainable Palm Oil (MSPO) is the national standard in Malaysia which seeks to promote sustainability of the oil palm industry. It was launched in 2013 and the implementation of the certification scheme started in 2015 on a voluntary basis. The targeted mandatory implementation for the whole industry is 31 December 2019 with effect on the 1 January 2020. With the mandatory implementation of MSPO, the industries have prioritised their commitment towards sustainability, including smallholders. In Malaysia, independent smallholders play a vital role in the palm oil industry and occupy over $16 \%$ of total oil palm land area. This article looked at the transformation of independent smallholders based on an amended conceptual transformation model developed and review from some of the MSPO audit findings among the independent smallholders. It was observed that there is an enhancement in the three elements of sustainability which are environment, social and economy among the smallholders through implementation of MSPO, thus, suggesting further strengthening the transformation of the smallholders by improving the management system of the smallholders.
\end{abstract}

Keywords: sustainability, MSPO certification system, social aspect, environmental aspect, economic aspect.

Date received: 26 March 2019; Sent for revision: 27 March 2019; Received in final form: 3 July 2019; Accepted: 26 July 2019.

\section{INTRODUCTION}

As the second largest palm oil producer in the world, Malaysian palm oil industry has been striving to meet the worldwide demand for sustainable production of palm oil by implementing various certification be it foreign or national certification (Aikanathan et al., 2015). Palm oil industry has fuelled the economic growth of Malaysia with capacity to supply 34\% of the world's palm oil production (Kushairi et al., 2019). The demand for palm oil is increasing and the

\footnotetext{
Malaysian Palm Oil Board,

6 Persiaran Institusi, Bandar Baru Bangi,

43000 Kajang, Selangor, Malaysia.

E-mail: nazira@mpob.gov.my
}

production is projected at 72 million tonnes by 2019 with Malaysia and Indonesia as leading producers (MPOC, 2019). The increasing demand is due to the firm establishment of the oil palm industry and versatility of the palm oil itself. Palm oil is known for its relatively higher production per hectare in comparison to other oil crops which makes it more competitive compared to other oils (Oil World Annual, 2015). However, the palm oil industry is currently facing numerous challenges where sustainability has become the pivotal issue.

Malaysia as one of the major players in this industry is facing several challenges in sustainability and accusations that this industry causes adverse impacts related to the environment. Chye et al. (2015), named three major impacts from the oil palm; 
environmental, social and economic impacts. Land clearing from the expansion of oil palm plantations that affects forest ecological function and threatens the endangered species, threat to livelihood of indigenous people and fluctuation of palm oil market price are among the issues highlighted. On the contrary, Basiron et al. (2012) countered that oil palm is not the main cause of deforestation. He cited a FAO study that the main driver of deforestation is the livestock industry and oil palm only occupied $0.3 \%$ of the land area used for agriculture. In addition, there are recent studies that have attempted to improve biodiversity conservation in oil palm production areas. Among them are a study on landscape heterogeneity which was conducted in Peninsular Malaysia to improve biodiversity in oil palm certified area (Azhar et al., 2015) and another study on alley-cropping system which can boost biodiversity and ecosystem functions in oil palm plantations (Ashraf et al., 2018).

Despite the debate and criticism on the sustainability of the production of this commodity, various efforts have been made by Malaysia to capture the concept of sustainability for nationwide adoption. The ideas and concepts of sustainability have been raised from several sources. Theoretically, Brundtland defined sustainable development as the development that meets the needs of the present without compromising the ability of future generations to meet their own needs (Brundtland, 1987). On the other hand, sustainability as defined by Mitcham (1995) is improving the quality of life for the present and future while protecting the quality of environment and promoting responsible use of natural resources. The United Nations has come out with the concept of sustainable agriculture which includes six main principles (United Nations, 2013): Principle 1: aim for food security; Principle 2: be environmentally responsible; Principle 3: ensure economic viability; Principle 4: respect human rights, create decent work and help communities to thrive; Principle 5: encourage good governance and accountability; and Principle 6: promote access and transfer of knowledge, skills and technology.

Based on broad definition of sustainability, to be sustainable, oil palm industry has to shift direction from a profit-driven business to a more sustainably sound business that falls within three major dimensions of economic growth, environmental protection and social impacts, or so called 3Ps People, Planet and Profit. Sustainability standards are proposed to underpin a new governance model for the global palm oil industry. One of the means to measure the extent of the implementation is through third party examination of certification systems implemented.

For Malaysia, despite the existing foreign voluntary sustainability standards for palm oil such as the Roundtable Sustainable Palm Oil (RSPO) and
International Sustainability Carbon Certification (ISCC), the palm oil industry together with the Malaysian Palm Oil Board (MPOB) has developed a standard named as Malaysian Sustainable Palm Oil (MSPO) at the instruction of the then Ministry of Plantation and Commodity (MPIC). MSPO covers the general requirements of sustainability principles and criteria for the production of certified sustainable palm oil and include four parts; Part 1: guidelines for Malaysian Sustainable Palm Oil, 2. Part 2: general principles for independent smallholders, Part 3: general principles for oil palm plantations and organised smallholders, and Part 4: general principles for palm oil mills.

The main idea for establishing MSPO is to have a locally adapted standard which incorporates the interests of small and medium producers in complying with sustainability criteria which was not recognised during the development of RSPO nor ISCC (Kuntom et al., 2015).

\section{MSPO FOR SMALLHOLDERS}

In Malaysia, smallholders in the oil palm supply chain fall broadly into two main categories; independent smallholders and organised smallholders. Independent smallholders are individual farmers who own or lease 40.46 ha or less of an oil palm smallholding and manage the holding themselves or employ workers. As of December 2018, there were a total of 255615 independent smallholders in Malaysia with a total area of 994022 ha, which accounted for $17 \%$ of the total oil palm planted area of 5.85 million hectares (Kushairi, 2019).

The second category of smallholder is the organised smallholders, which are managed by government agencies such as Federal Land Development Authority (Felda), Rubber Industry Smallholders Development Authority (RISDA), Federal Land Consolidation and Rehabilitation Authority (Felcra), Sarawak Land Consolidation and Rehabilitation Authority (SALCRA), Sabah Land Development Board (SLDB) and other state agencies. To date, the total number of organised smallholders in Malaysia is 315293 with the total land area of 682269 ha.

Under MPOB, independent smallholders are grouped into Sustainable Palm Oil Clusters (SPOC), i.e. groups of independent smallholders operating within a specific boundary and are committed to produce oil palm fresh fruit bunches (FFB) under a programme developed, managed and monitored by MPOB. Under the SPOC programme, Sustainable Palm Oil Growers Cooperative (KPSM) was established to help smallholders to improve production and quality of FFB produced. These smallholders are being assisted by extension officers 
or Tunjuk Ajar Nasihat Sawit officers (TUNAS MPOB) in various areas to help them manage their farm.

The role of smallholders in contributing to national output is undoubtedly important. Nagiah et al. (2012), emphasised that smallholders, mainly in Indonesia and Malaysia, together produce a substantial amount of the worlds' palm oil, which is as much as $85 \%$ of the total output and accounts for up to $40 \%$ of the total planted area. The huge role of smallholders in the development of palm oil industry was also highlighted by Rahman et al. (2008) on how efficiency of smallholders in oil palm production affects overall supply chain because their cumulative size is comparatively large.

Hidayat et al. (2015), emphasised that smallholders play a vital role in the palm oil industry but they are also an economically vulnerable group. The vulnerability of this group is mainly due to their lack of knowledge in maintaining their farms which subsequently reduce their productivity, lack of financial support and, uncertainty about market access price. According to Ismail et al. (2003), the major problem faced by smallholders is the high cost of production that compelled them to use poor quality input materials in order to save cost. This has led to low productivity and poor quality of FFB and hence the palm oil produced is also of low quality.

In recognition of these factors, Parts 2 and 3 of MSPO have been developed to incorporate independent and organised smallholders respectively into a comprehensive and reliable sustainable standard. These two standards which were developed with respect to practicality of smallholders in compliance with sustainability requirement consist of seven main principles, each supported by criteria and indicators. In addition to this, the Prime Minister of Malaysia had announced mandatory implementation of MSPO and, independent and organised smallholders were given a grace period until 31 December 2019.

Table 1 lists the seven principles of MSPO. Theoretically, Principle 1 indicates the requirement to prove the commitment of the management to implement MSPO. A policy is necessary to reflect

TABLE 1. THE SEVEN PRINCIPLES OF THE MALAYSIAN SUSTAINABLE PALM OIL (MSPO)

\begin{tabular}{|c|c|c|}
\hline No. & & Principles \\
\hline 1 & Principle 1 & $\begin{array}{l}\text { Management commitment and } \\
\text { responsibilities }\end{array}$ \\
\hline 2 & Principle 2 & Transparency \\
\hline 3 & Principle 3 & Compliance to legal requirements \\
\hline 4 & Principle 4 & $\begin{array}{l}\text { Social responsibility, health, safety } \\
\text { and employment condition }\end{array}$ \\
\hline 5 & Principle 5 & $\begin{array}{l}\text { Environment, natural resource } \\
\text { biodiversity and ecosystem }\end{array}$ \\
\hline 6 & Principle 6 & Best practices \\
\hline 7 & Principle 7 & Development of new plantings \\
\hline
\end{tabular}

the commitment of the management in adopting sustainable practices through the implementation of MSPO. Under this principle, management also has to show the continual improvement in their practices by regular monitoring, including internal audit or management review. Other activities such as adoption of new technologies, or engagement with stakeholders that will improve the management can be classified as one of the indicators and must be recorded.

Principle 2 emphasises on transparency and traceability. The premises are required to provide relevant information transparently to make sure that the end product can be traced to sustainable raw materials. Records related to operational activities and any transactions done must be updated and being able to be checked by auditors when required. Management should also be able to communicate in transparent manner during communication or consultation during any interaction.

Under Principle 3, oil palm premises are required to comply with regulatory requirements, such as laws and regulations pertaining to planting oil palm, and processing of FFB and other palm products.

Principle 4 emphasises on social responsibility, health and safety, and employment condition. human rights including indigenous and customary rights, social equality and contribution to positive social impact to community and people are also highlighted. Therefore, the organisations should show commitment to contribute to local sustainable development, ensures employees health and safety, fair employment conditions, and training to enhance competency of the workers. The organisation should also conduct and address social impact assessment, complaints and grievances.

The environmental aspect of Principle 5 encompasses environment, natural resources, biodiversity and ecosystem. In increasing awareness of environmental conservation, there are three major issues that concern industry most; greenhouse gas emission, open burning and deforestation. As such, the organisation should preserve the environment by implementing environmental management programme, efficiency of energy use, and use of renewable energy, waste management and disposal, reduction of pollution and emission, protection of natural water resources, status of rare, threatened and endangered species, high biodiversity value area, and zero burning practices.

Best Management Practices is under Principle 6 which emphasises that each organisation must develop best practices to obtain optimum productivity including site management, economic and financiall viability plan, transparent and fair pricing deals and also subcontracting of some of the operations to others. These are important for the continuity of the business and long-term sustainable business. 
Principle 7 focuses on development of new plantings where among major concerns are considerations for areas of high biodiversity values, deep peat land, planting on steep terrain, and issues pertaining to indigenous well-being before development of new planting. To ensure that there will be no issues after planting, soil survey and environmental and social impact assessment (SEIA) should be conducted as part of the planning.

\section{MSPO Certification System}

To ensure impartiality, certification of MSPO standards has to be conducted by independent certification bodies (CB) and there are 16 certification bodies across Malaysia. The CB must comply with the requirements of ISO/IEC 17021, international standards for body operating audit or other system acceptable to and endorsed by Standards Malaysia. The auditing procedure for MSPO follows standard auditing procedure from application to certification, with addition of a few processes to ensure that elements of sustainability and transparency are well captured in the certification system such as stakeholder consultation and panel review. The procedure of certification is shown in Figure 1.

\section{CHALLENGES AND TRANSFORMATION OF SMALLHOLDERS}

Despite the increasing number of MSPO certified smallholders, the true challenge is the effectiveness of MSPO implementation in the field through the certification system. The question is whether these sustainability standards can enhance the transformation of the smallholders to a more sustainable environment, business and livelihood. As far as certification is concerned, it has always been contentious that the number of certified premises is a true indicator of the performance of the certification scheme.

In general, Abdul and Corner (2009) mentioned that most studies do not generally address the impact of the implementation of quality management system through certification process on the organisations, hence, leading to argument. Adolfas (2010) also concluded that organisations with different implementation of quality management systems have significantly different performance patterns. Despite the success of organisations in being certified to quality management system, certification has always been criticised as not a risk-free undertaking. Bhuiyan and Alam (2005), classified certification as time and resource consuming, too formalised, and that implementation costs are greater than the benefits derived.

However, it is undeniable that certification is necessary for market access and has always been used as a tool to reflect reputation and quality of the product or services. For the palm oil industry, the trend of global demand has seen shifting towards certified sustainable palm oil where certification plays its role to control market demand and supply, directly or indirectly.

Cosmin et al. (2015), also stressed that, having certification is a proof that they are deploying special efforts to function according to high quality standards and it apparently could be an indicator of awareness of the obligations relating to its purpose. In a narrow context, Hidayat et al. (2015), have revealed in their conclusion that participation of Indonesian palm oil farmers in certification (in their case, RSPO), has led to organisational and technological changes that induce a higher production quality that benefit smallholders indirectly and financially although it does not change the farmer's economic vulnerability and access to the market.

\section{METHODOLOGY}

In the context of MSPO, to better understand the transformation of smallholders through this certification process, we selected one of the credible transformation conceptual models to examine the relationship between MSPO certification and transformation of the smallholders. Based on the selected model and review of results from some of MSPO audit findings, the following discussion is on the research method used and the outcomes of research. This article will particularly focus on the most complex group in the supply chain, independent smallholders which is under MSPO Part 2: general principles for independent smallholders.

\section{Transformation Conceptual Model}

We used an amended form of the Edosomwan 6Rs of Organisational Transformation and Reengineering to examine the underline concept of transformation of independent smallholders through MSPO. Edosomwan (1996) integrated both methodology and framework approaches in this model which we believe is partly in line with the concept of MSPO certification process. To analyse the transformation process, there are five main focus points in this model; management system, social system, technical system, behavioural system and critical competitive factors. Edosomwan also defined six key elements activities which should be done during transformation; requirements (customers, process owners, suppliers, products, services), rethink (structure, systems, procedures, rules, process and technologies), redesign (the whole system, reduce waste, process optimisation, output optimisation), retool (competitive 


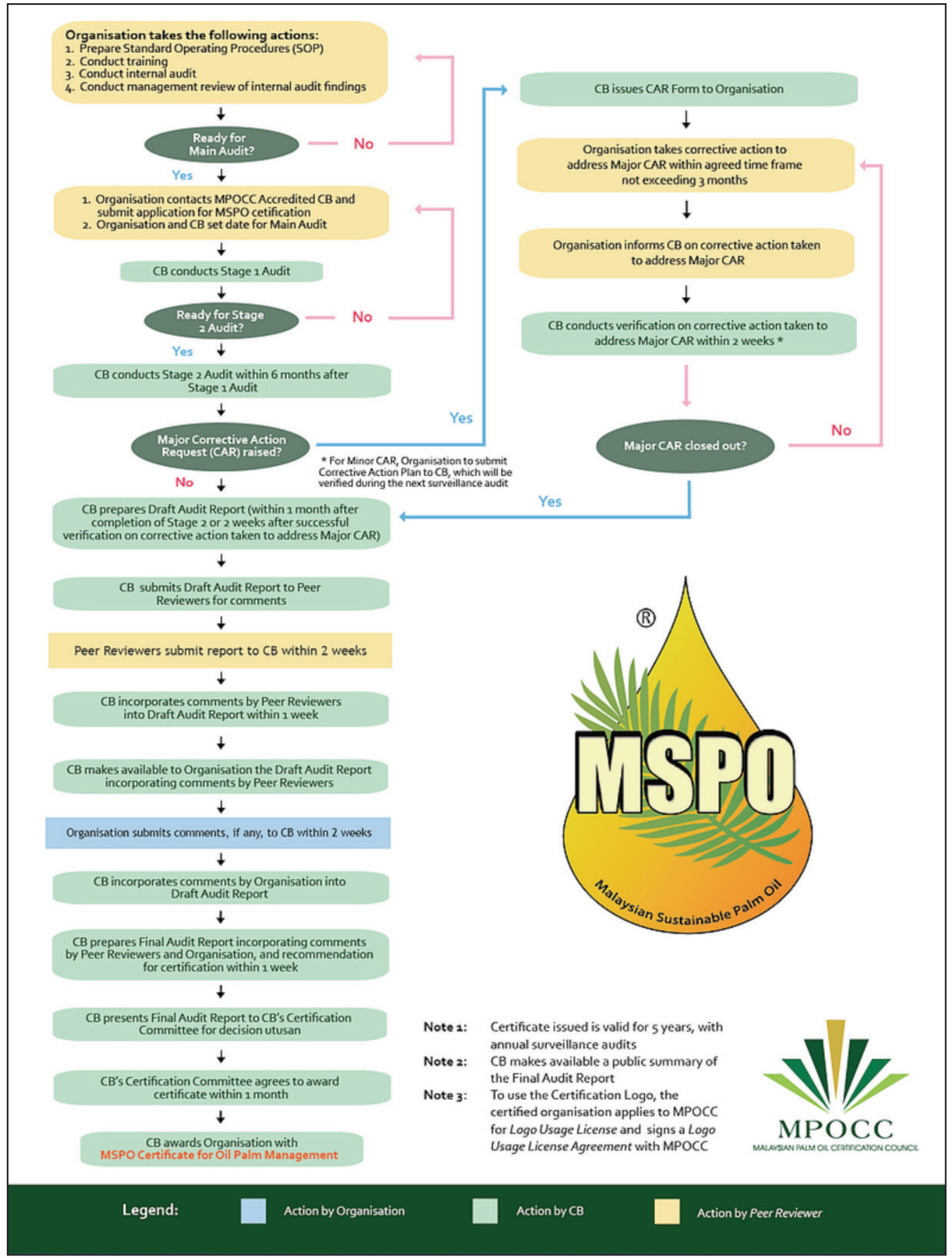

Source: MPOCC (2019).

Figure 1. Malaysia Sustainable Palm Oil (MSPO) Certification procedure.

technologies, technological systems, supply systems, transformation models, reevaluate (results, goal, metrics) and realisation (challenges, need, opportunities, strength). Delivering outputs and results expected are customer satisfaction, productivity, cost reduction, service and product quality, efficiency and effectiveness and high morale of employees.

Figure 2 is our amended framework from Edosomwan key element model that connect MSPO certification to transformation of smallholders. Based on this framework and conceptual model, we 


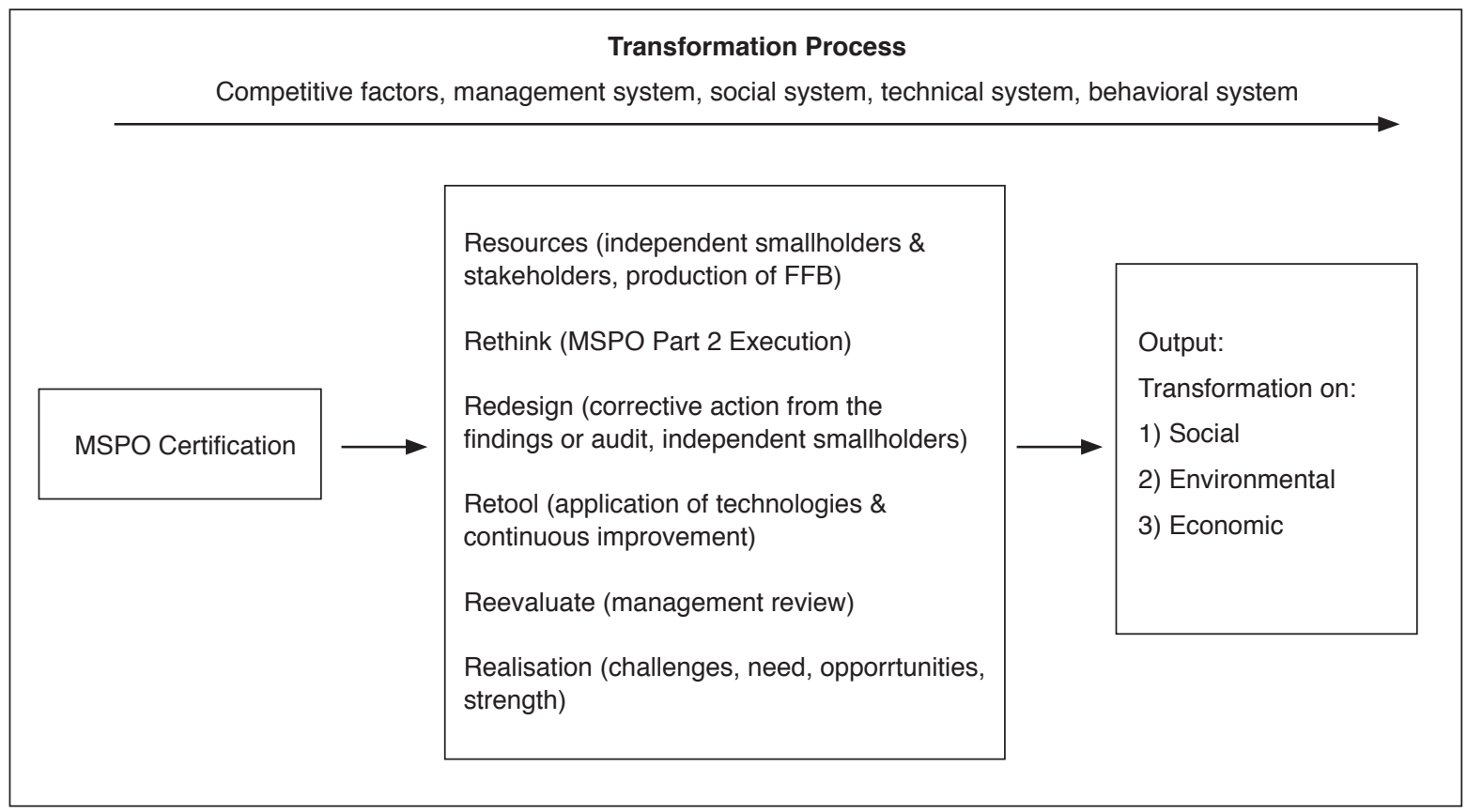

Figure 2. Framework amended from Edosomwan (1996).

believe that MSPO certification has the potential to ensure transformation of independent smallholders through the process and elements within the MSPO execution.

Using the amended model as a starting benchmark, this study examined the process of MSPO's execution, which comprised all the elements of the model and provided insightful output. In order to ensure transformation of independent smallholders specifically in the sustainability dimension, one of the main important elements is capacity building, which is under the element of resources. Capacity building is the backbone of the transformation and the focus is on how the sustainability criteria of MSPO is to be executed by independent smallholders through optimising all elements as the model above. Therefore, utilisation of resources in the first place, including the independent smallholders themselves and the stakeholders is pivotal.

In the context of resources as an element of transformation through MSPO, the nature of certification itself has had helped smallholders to move to a higher standards. To comply with MSPO requirements, smallholders need to give commitment and widen their knowledge on the sustainability aspects related to their operation. They are also exposed to more open environment and being monitored by the third party, certification bodies

The Malaysian government realises that it is a challenging task due to complexity of the group. Although they represent small scale production entity, it has always been perceived that this sector is inefficient and unproductive. As discovered by Malek and Barlow (1988), among the most challenging problems faced by this group are high production cost, scarcity of labour and land, poor extension, and lack of finance for planting. Considering the financial constraint that might be faced by this group, the government through MPOB provides financial assistance including full coverage of certification cost, cost of Personal Protective Equipment (PPE) and chemical store/ rack. Moreover, MPOB as the custodian of oil palm industry is also responsible for providing technical assistance for the execution of MSPO by smallholders.

MSPO is the national system and will bring about drastic changes to the oil palm industry. The implementation of a sustainable standard which is new to smallholders requires structural changes in management, technical and social system on a large scale. For that, MPOB had restructured the SPOC system and registered the system under trademark SPOC governed by the Intellectual Property Corporation (MPOB, 2018a) for the purpose of MSPO, which was initially established to organise the smallholders into small group to enable them to work together to improve their productivity and income. From 10 clusters nationwide which had been identified as pioneers for the setting up of the SPOC in 2009, now there are 162 SPOC nationwide. All the smallholders from West Malaysia to East Malaysia will be included in MSPO implementation under these SPOC with no exception.

Under the umbrella of SPOC, there is a unique mechanism in which all stakeholders involved in the system will help to strengthen the execution of MSPO. Figure 3 shows the mechanism in the management of SPOC. 


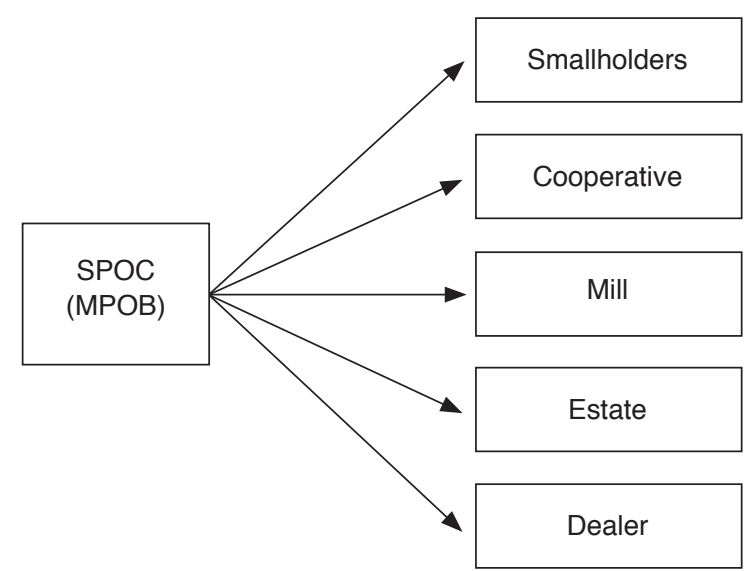

Figure 3. Mechanism in management of Sustainable Palm Oil Cluster (SPOC).

Instead of being managed solely by MPOB, smallholders' groupings may also be under the management of cooperative, mill, estate or dealer. This structural strategy has led to betterment of the SPOC management and ensures that all stakeholders and resources in the circle of the smallholders will be involved in the process.

Under these, all SPOC members will be guided by a group manager who might be a MPOB TUNAS officer, dealer, mill or any other relevant person/ organisation. Group managers will be monitored under the management of the Internal Control System (ICS) where they are bound.

The group manager must have adequate technical knowledge to support and assist the participating members and to ensure that all members in the group comply with relevant MSPO standards. In particular, the group manager shall manage the group contracts with the group members, establish and implement an ICS within the group, conduct the group self-assessment, issue internal corrective action to any participating members, and other relevant roles.

Instead of resources, MSPO requires transformation under the element of Rethink and Retool which includes transformation in procedures, rules, process and technologies for compliance with MSPO requirement. At management level, MPOB provides a set of procedures and rules that are linked to the MSPO standard requirements to be applied by the smallholders. Among the procedures are complaints and grievances procedure, handling and disposal of chemicals procedure, economic and financial plan procedure, and disposal of schedule waste procedure. Smallholders are also provided with guidelines on safety and health, protection of buffer zone and zero burning practices.

Along the certification process, the smallholders together with their group managers, particularly under SPOC, may need to redesign, retool and reevaluate the effectiveness of their management system through improvement of current system or even application of new technologies.

These are the activities of MSPO execution among the smallholders and it was proven to be successful. As evidence, to date, there are 120 SPOC all over Malaysia that have been MSPO certified.

Based on conceptual model and theoretical structure, the output in the form of transformation will be discussed in three main aspects; social, environmental and economic. To support the theoretical findings from the review of the conceptual model, we also reviewed some of MSPO audit findings.

\section{RESULTS}

\section{Audit Findings During Certification}

The results of implementation of MSPO by independent smallholders were obtained from the compliance analysis based on 40 audits that have been carried out at various SPOC under the management of MPOB TUNAS officers. Audits were conducted by $\mathrm{CB}$ based on initial review of self-questionnaire, Stage 1 and 2 Audit assessments. An initial review self-questionnaire was conducted to determine the risk factor and the number of independent smallholders to be sampled during the audits as per MSPO sampling guideline in Accredited Certification Bodies - Oil Palm Management Certification 2 - Audit Duration for Certification Bodies Operating Oil Palm Management (ACB-OPMC 2) by the Accreditation Body (Standard Malaysia, 2017). The Stage 1 Audit was conducted to see the readiness and adequacy of smallholders' understanding of the requirements of MSPO standard, in particular with respect to the identification of key performance of the cluster in relation to the significant aspects, processes, objectives and operation of the SPOC management system. Stage 2 Audit was conducted in order to evaluate the implementation, including the effectiveness of MSPO documentation, which included information and evidence about conformity to all requirements of the applicable management system standard or other normative document. During the audit, methods used to obtain information were through interviews, observations of processes and activities, review of documentation and records.

In stages 1 and 2 of the 40 audit reports of SPOC, 134 non-compliance in total were issued, which comprised of major non-conformities (73) and minor non-conformities (61). Detailed number of non-compliance issues according to the stage of audits are as per Table 2 .

Based on Table 2, it was observed that the highest frequency of major and minor non-compliances during Stage 1 and Stage 2 Audits were on 
TABLE 2. NUMBER OF NON-COMPLIANCE ISSUES ACCORDING TO STAGE OF AUDITS

\begin{tabular}{|c|c|c|c|c|}
\hline $\begin{array}{l}\text { Audit } \\
\text { type }\end{array}$ & $\begin{array}{l}\text { No. of sample } \\
\text { audit reports }\end{array}$ & $\begin{array}{c}\text { No. of major } \\
\text { non-conformities issues }\end{array}$ & $\begin{array}{c}\text { No. of minor } \\
\text { non-conformities issues }\end{array}$ & $\begin{array}{c}\text { Total } \\
\text { non-conformities issues }\end{array}$ \\
\hline Stage 1 & 14 & $\begin{array}{l}\quad 44 \\
\text { Principle } 1(7) \\
\text { Principle } 2(8) \\
\text { Principle } 3(3) \\
\text { Principle } 4(10) \\
\text { Principle } 5(10) \\
\text { Principle } 6(6) \\
\text { Principle } 7(0)\end{array}$ & $\begin{array}{l}22 \\
\text { Principle } 1(0) \\
\text { Principle } 2(0) \\
\text { Principle } 3(1) \\
\text { Principle } 4(3) \\
\text { Principle } 5(10) \\
\text { Principle } 6(7) \\
\text { Principle } 7(1)\end{array}$ & 66 \\
\hline Stage 2 & 26 & $\begin{array}{l}29 \\
\text { Principle } 1(1) \\
\text { Principle } 2(7) \\
\text { Principle } 3(2) \\
\text { Principle } 4(6) \\
\text { Principle } 5(8) \\
\text { Principle } 6(5) \\
\text { Principle } 7(0)\end{array}$ & $\begin{array}{l}39 \\
\text { Principle } 1(3) \\
\text { Principle } 2(0) \\
\text { Principle } 3(4) \\
\text { Principle } 4(11) \\
\text { Principle } 5(11) \\
\text { Principle } 6(10) \\
\text { Principle } 7(0)\end{array}$ & 68 \\
\hline Total & 40 & 73 & 61 & 134 \\
\hline
\end{tabular}

Principles 4 and 5. Principle 4 emphasises more on social responsibility, health, safety and employment condition. Under the criteria of complaints and grievances, an independent smallholder should be able to respond to complaints that were raised by their neighbours or other stakeholders.

However, based on the audit findings, there were some independent smallholders, who were not aware of how to lodge complaints even though a system for dealing with complaints and grievances has been established and documented by the SPOC management system. Therefore, non-compliance was raised by the auditor under this principle. The SPOC manager would take corrective actions by educating the independent smallholders in the group on the complaint procedure in order to close the non-compliance issues.

The other non-compliance issue was under the criteria of employee's safety and health. An independent smallholder shall ensure that all work practices are safe. There is a procedure for safe work practices in the palm oil field covering harvesting and fertiliser application activities, PPE to be used such as safety boots, helmet, goggle, face mask, apron, gloves and long sleeve shirt. There is no specific mechanism established by the management system to monitor on the usage of PPE among the smallholders. However, the importance of compliance against safety and health requirements were always emphasised by the TUNAS officers during their visit to the smallholders' farm. The audit findings also reported that there was noncompliance under the criteria of training and competency of the smallholders. SPOC managers had provided training for all members which cover on aspects of Good Agricultural Practices
(GAP), safety, MSPO awareness, etc. However, the effectiveness of the training given to the smallholders need to be improved because some of the smallholders did not understand on GAP, specifically the spraying technique. This audit finding was reported based on the interview and observation of blanket spraying by the smallholders during the certification body visit to the farm.

Principle 5 emphasises more on environmental, natural resources, biodiversity and ecosystem services. Common non-compliance found under this principle was related to the waste management disposal and identification of species of habitats. All smallholders who participated in the MSPO certification were given training on proper disposal of hazardous chemicals and their containers as per local and national legislation.

Basic understanding on the environmental issues and protection of environment by not practicing open burning, empty chemical containers are disposed after triple rinse method and not dumped in the farm were also conveyed to the smallholders. Only a small number of smallholders did not dispose the waste appropriately which led to the issuance of non-compliance by the auditors. Based on the interview, smallholders lacked the knowledge on species or habitats of concern including their conservation needs. Instead of giving awareness on this topic to the smallholders, SPOC managers had provided the contact with a number of agencies such as Wildlife Department and Forestry Department, so that the smallholders could get the information on the protected species and their habitat with high biodiversity value.

Other non-compliance issues for the smallholders were related to the record keeping 
and also traceability which fall under Principle 2. Smallholders were usually trained in record keeping, however, not all smallholders used to document their farm activities and record keeping proved notably challenging when smallholders were illiterate. Record keeping is one of the best practices in order to make smallholders more aware of their activities; cost incurred and also the profit that they would get from the cultivation of oil palm.

\section{Transformation of Smallholders in Social Aspects}

In general, independent smallholders have social and network limitations as most of them work individually without external help. Different from organised smallholders, independent smallholders especially those living in remote areas, have difficulties to access information or to get help to manage their operation. The implementation of MSPO makes them reliant on external actors or so called stakeholders. For independent smallholders clustered into a SPOC, any operation related to management is under the responsibility of a group manager. The group manager who might be a TUNAS officer, a dealer, a mill or any other relevant person/organisation will facilitate the members.

Through each SPOC, smallholders are assisted to manage their business in an organised manner including record keeping and filing, and they have a platform to better communicate with other stakeholders such as mill, dealer, or supplier. With the mandatory of MSPO, there is a growing awareness among the FFB dealers to be part of certification process by volunteering to be a group manager.

In addition, to fulfil the requirement of MSPO specifically Principle 4, smallholders are given training on various areas of concern, including GAP, safety and health, environment and awareness of MSPO itself. To date, hundreds of trainings have been conducted to all smallholders participating in MSPO all over Malaysia in collaboration with other government agencies such as Department of Safety and Health (DOSH), Department of Environment (DOE), Department of Wildlife Protection (PERHILITAN) and other state agencies. The effectiveness of the trainings conducted is validated by auditors where they investigate the smallholders awareness and their living use of the learnings during the audit visit.

Hidayat et al. (2015), indicated that although the impact in the social aspect is not really visible and is seen as a long-term effect, certification has required the participants to at least practice minimum requirements that are actually very important to them such as in the aspect of safety and health and social responsibilities. In line with this, MSPO emphasises the aspect of safety and health in Principle 4 for social responsibility, health, safety and employment condition.
Smallholders who join MSPO under SPOC are provided with PPE and are trained by the group managers to use it for their operations such as applying fertiliser, chemicals and harvesting. MPOB also provides individual store and centralised storage at their premises in order to make sure that all chemicals used by smallholders are properly managed. With this financial assistance, there is no issue of smallholders refusing to buy PPE and practising safe working conditions because of cost constraint.

In addition, through MSPO, smallholders are also required to have good relationship with other stakeholders that would be affected by their operations and hence, they interact with stakeholders to ensure harmonious relationship by creating a platform for complaints and stakeholders consultation in the MSPO system. This has built a positive circle of social relationship where everybody in the certification has been put in a winwin situation.

\section{Transformation of Smallholders in Environmental Aspects}

The increasing awareness on sustainability for the production of palm oil requires a drastic change in environmental awareness among smallholders. As global attention has been focused on environmental implications from the expansion of oil palm plantations such as land deforestation, and loss of biodiversity, smallholders as one of the major players obviously need to be incorporated into any efforts related to conservation of the environment. Smallholders have to transform themselves to a higher state where they need to understand and implement good practices to enhance environmental quality.

In MSPO, conservation of environment, natural resource biodiversity and ecosystem are achieved through the implementation of Principle 5. In view of this, smallholders joining MSPO are seen as having undertaken several efforts in protecting the environment such as maintaining riparian buffer zone, and conserving water and soil quality through good agricultural practices. They are also exposed on how to manage schedule waste and pesticides. MPOB and related agencies such as DOE and DOSH also conducted continual training to educate the smallholders on how to reduce contamination of chemicals to the environment. Smallholders are also introduced to the concept of wildlife protection and to the list of threatened, endangered and rare species which need to be protected by PERHILITAN. Information is included as guidance on how to handle wildlife-human conflict.

Smallholders that are involved in new planting, need to comply with Principle 7. This principle addresses all requirements for development of new 
plantings areas that include important aspects of environmental conservation such as identification of high biodiversity areas and deep peat land. Appropriate agronomic practices also need to be implemented during the development. Although the effectiveness of the implementation in terms of the environmental may not be directly apparent yet, the efforts done by smallholders to comply with the requirements should be highly acknowledged.

\section{Transformation of Smallholders in Economic Aspects}

Improving the economy of smallholders is a big issue. The average Malaysian smallholder only has a land holding of about 3.9 ha. This hectarage is considered not economical because it can only generate a net income of around RM 1600 per month/family (Table 3). This income is considered below the Malaysian poverty line. Although the average income of the smallholders was not categorised as hardcore poverty, the smallholders still have to provide for their family through other means such as integration with other crops or farm animals.

How can sustainable palm oil transforms the economy of smallholders? The realistic approach is by increasing their FFB productivity. The smallholders can increase their FFB yield up to $30 \mathrm{t} \mathrm{ha}^{-1} \mathrm{yr}^{-1}$. It is possible to achieve this yield if they really take care of their farm and adopt the good agricultural practices (GAP) recommended to the smallholders. The small land ownership by the smallholders should make it easy for them to manage their farm with the GAP. As of December 2017, 1307 smallholders have produced more than $30 \mathrm{t} \mathrm{ha}^{-1} \mathrm{yr}^{-1}$ FFB (MPOB, 2018). This proves that smallholders' yield can be just as good as the estates or even better.

Principle 6 in the MSPO states that the smallholders need to adopt best practices or GAP in order to get MSPO certification. Study by Nur et al. (2016), showed that adoption of GAP practices

TABLE 3. NET INCOME OF INDEPENDENT SMALLHOLDERS IN 2017

\begin{tabular}{lr}
\hline \multicolumn{1}{c}{ Items } & Value \\
\hline 1. FFB yield per hectare $\left(\mathrm{t} \mathrm{ha}^{-1} \mathrm{yr}^{-1}\right)$ & 17.19 \\
2. Average FFB price per tonne $\left(\mathrm{RM} \mathrm{t}^{-1}\right)$ & 518 \\
3. Gross income per hectare $\left(\mathrm{RM} \mathrm{ha}^{-1} \mathrm{yr}^{-1}\right)$ & 8904.42 \\
4. Cost of FFB production per tonne $\left(\mathrm{RM} \mathrm{t}^{-1}\right)$ & 230 \\
5. Cost of FFB production per hectare $\left(\mathrm{RM} \mathrm{ha}^{-1}\right)$ & 3954.70 \\
6. Yearly net income per hectare $\left(\mathrm{RM} \mathrm{ha}^{-1}\right)$ & 4949.72 \\
7. Average land holding & 3.9 \\
8. Monthly net income per land holding $(\mathrm{RM})$ & 1608.66
\end{tabular}

Note: FFB - fresh fruit bunch.

Source: MPOB (2018b). among 400 smallholders was only $26 \%$. This was the biggest challenge for the smalllholders. They need to change their attitude to be proactive. Through MSPO, smallholders will be taught with GAP which guide them to manage their farm such as by using suitable fertilisers with recommended rates, the proper way to use pesticides and herbicides, the proper harvesting technique and how to maintain soil moisture. These practices will definitely help in maximising productivity, minimising cost of production and indirectly will increase the smallholders' income.

Besides GAP, smallholders are also taught on how to keep records of their farm management especially on monthly yield, production costs such as buying fertiliser, labour cost for harvesting, transportation of the FFB, etc. It is important for smallholders to monitor their cost of production. Most of the smallholders in Malaysia do not keep proper records of their farming activities and they will have difficulty in determining their actual costs and profits (Ayat et al., 2008). Previous study by Engler and Toledo (2010) showed that record keeping practices among farmers in Chile help them to keep and analyse data on economics and production.

The government through MPOB has established KPSM in the SPOC all over Malaysia. Smallholders in each respective SPOC are encouraged to register with the KPSM. The cooperative is one of the models used in meeting the needs of local community development to help eradicate poverty while solving the problems (Tomaquin, 2014; Nuqussie, 2010). KPSM provides an option for the smallholders to solve their middleman dilemma in selling the FFB. By joining the cooperative, smallholders have good alternatives to address their problems and help them to improve their standard of living. The main advantage of the cooperative is that their voices will be heard as they represent a big group of peoples.

As of December 2018, 55 KPSM have been established in Malaysia with two core activities, which are group selling of FFB to the mills and group purchase of agricultural inputs especially fertilisers (Nazirah and Zaki, 2018). A group purchase in agricultural inputs can reduce cost and group selling of FFB can obtain optimal price, thus increasing income of KPSM members. In 2018, the total sale of FFB by 30 KPSM was recorded at $150350 t$ (MPOB, 2018b). Besides increasing the members income, establishment of KPSM is also indirectly creating healthy business competition with others FFB collection centre such as the increment in FFB price offered by other FFB collection centres (Ismail et al., 2015; Nazirah et al., 2012). Study conducted by Sarmila et al. (2016), has shown that there is a potential of agricultural cooperatives to increase the existing community income and enhancing the economy of a community. Therefore, the 
transformation of smallholders in terms of economic aspect through MSPO certification is worthwhile.

\section{CONCLUSION}

From the amended conceptual model we developed as the benchmark of this study, we provide some insight in terms of relationship between the system of MSPO and the transformation of Malaysian independent smallholders in social, environmental and economic aspects. We found that the unique mechanism of the SPOC system where Malaysian independent smallholders are bound, and the elements inside MSPO which are in line with the conceptual model including resources, structural and management system have led to dynamic transformation of the smallholders in terms of social, environmental and economic aspects. Our study reveals that through MSPO, Malaysian independent smallholders have transformed themselves from being reliant to some of external factors to a higher level of society or a more sustainable community along with the process of MSPO certification. This study has been the first insight of the transformation of independent smallholders in Malaysia through MSPO, this we expect to help further explore ways to strengthen the livelihood of the smallholders and also to improve the smallholders management system. Auditing findings showed that the smallholders need guidance during the implementation of MSPO certification and corrective actions of all noncompliance that occurred.

\section{ACKNOWLEDGEMENT}

The authors thank the Director-General of MPOB for permission to publish this article. We would also like to thank research officers from various divisions for their support during the implementation of MSPO certification.

\section{REFERENCES}

Abdul, W and Corner, J (2009). Critical success factors and problems in ISO 9000 maintenance. Int. J. Qua. Rea. Man., 26(9): 881-893.

Adolfas, K (2010). Success factors for quality management systems: Certification benefits. Int. Eco., 2(8): 30-38.

Aikanathan, S; Basiron, Y; Sundram, K; Chenayah, $S$ and Sasekumar, A (2015). Sustainable management of oil palm plantation industry and the perception implications. J. Oil Palm, Env. and Health, 6: 10-24.
Ashraf, M; Zulkifli, R; Sanusi, R; Tohiran, K A; Terhem, R; Moslim , R and Azhar, B (2018). Alley -cropping system can boost arthropod biodiversity and ecosytem functions in oil palm plantations. Agr. Eco. and Env., 260: 19-26.

Ayat, K A R; Ramli, A; Faizah, M S and Mohd, A S (2008). The Malaysian palm oil supply chain: The role of the independent smallholders. Oil Palm Industry Economic J. Vol. 8 (2): 17-27.

Azhar, B; Saadun, N; Puan, C L; Kamarudin, N; Aziz, N; Nurhidayu, S and Fisher, J (2015). Promoting landscape heterogeneity to improve the biodiversity benefits of certified palm oil production: Evidence from Peninsular Malaysia. Global Eco. and Con., 3: 553-561.

Basiron, Y and Yew, F K (2012). Land use effects of the livestock and oil palm industries. J. Oil Palm Env. and Health, 6: 1-9.

Bhuiyan, N and Alam, N (2005). An investigation into issues related to the latest version of ISO 900. Tot. Qua. Man., 16 (2): 199-213.

Brundtland, G H (1987). Report of the World Commission on Environment and Development: Our Common Future. An annex to document A/42/427 - Development and International Cooperation: Environment. United Nations Document. 101 pp.

Chye, I L; Wahidul, B and Yudi, S (2015). Review of existing sustainability assessment methods for Malaysians palm oil production. Procedia CIRP, 26:13-18.

Cosmin, D; Adriana, G; Mihaela, M and Oana, C (2015). Quality: A determinant factors of competitiveness - The evolution of ISO certifications for management systems. Proc. of the $9^{\text {th }}$ International Management Conference. p. 1062-1073.

Edosomwan, J A (1996). Organizational Transformation and Process Reengineering. St Lucie Press, Delray Beach, Florida, USA. p. 571-590.

Engler and Toledo (2010). An analysis of factors affecting the adoption of economic and productive data recording methods of Chilean farmers. Cieneia e Investigaction Agraria, 37(2): 101-109.

Hidayat, N K; Glasbergen, P and Offermans, A (2015). Sustainability certification and palm oil smallholders' livelihood: A comparison between scheme smallholders and independent smallholders. Int. Food and Agr. Man. Rev., 18(3): 25-48.

Ismail, A; Mohd, A S and Mohd, N M (2003) The production cost of oil palm fresh fruit bunches: The 
case of independent smallholder in Johor. Oil Palm Industry Economic J. Vol. 3(1): 1-7.

Ismail, A; Ahmad, S M and Shahrudin, Z (2015). Labour productivity in Malaysian oil palm plantation sector. Oil Palm Industry Economic J. Vol. 15(1): 1-10.

Kuntom, A; Kushairi, A and May, C Y (2015). Malaysian Sustainable Palm Oil. Oil Palm Bulletin No. 71: 1-7.

Kushairi, A; Meilina Ong-Abdullah; Balu Nambiappan; Hishamuddin, E; Vijaya, S; Izuddin, Z B; Razmah, G; Sundram, S and Parveez, G K A (2019). Oil palm economic performance in Malaysia and R\&D progress in 2018. J. Oil Palm Res. Vol. 31(2): 165-194.

MPOB (2018a). Sustainable Palm Oil Cluster (SPOC). Trademark Application Number 2019050203. $\mathrm{MPOB}$, Bangi.

MPOB (2018b). Integration Research and Extension Division Fact. Malaysian Palm Oil Board, Malaysia. Unpublished fact sheet.

Malek, M and Barlow, C (1988). The production structure of the Malaysian palm oil industry with special reference to the smallholders sub sector. PORIM Occasional Paper No. 24: 55 pp.

Mitcham, C (1995). The concept of sustainable development; its origin and ambivalence. Tech Soc., 17 (3): 311-326.

MPOC (2019). CPO Prices Trend: Views from Industry Expert. MPOC Palm Oil Internet Seminar (POINTERS), 18-24 February 2019.

Nagiah, C and Azmi, R (2013). A review on smallholders oil palm production: Challenges and opportunity for enhancing sustainability - A Malaysian perspective. J. Oil Palm Health, 3: 1-10.

Nazirah, C J and Zaki, A (2018). KPSM memperkasa masa depan pekebun kecil sawit. Prosiding Kebangsaan Pekebun Kecil Sawit 2018. MPOB, Bangi. p. 39-45.

Nazirah, C J; Zaki, A and Idris, O (2012). Koperasi sebagai institusi peningkatan produktiviti dan pendapatan pekebun kecil: Kajian kes Koperasi Penanam Sawit Mampan (KPSM). Prosiding Persidangan Kebangsaan Pekebun Kecil Sawit 2012. MPOB, Bangi. p. 99-108.

Nuqussie, W Z (2010). Why some rural people become members of agricultural cooperatives while others do not. J. Development and Agricultural Economics Vol. 2(4): 138-144.

Nur, H M; Nazirah, C J; Ainul, S S; Mohamad, A J; Amran, A; Nursuhan, D; Parthiban, K; Tan, S P; Kahirul, A; Shakir, A; Mohd, K I and Hamdan, A B (2016). Penerimaan Guna Amalan Pertanian Baik (GAP) di kalangan pekebun kecil sawit persendirian di Malaysia. Prosiding Persidangan Pekebun Kecil Sawit 2016. MPOB, Bangi. p. 169-183.

Oil World (2015). Oil World Annual. ISTA Mielke GmbH. 18 pp.

Rahman, A K; Abdullah R; Shariff, F M and Simeh, A (2008). The Malaysian palm oil supply chain: The role of the Independent smallholders. Oil Palm Industry Economic J. Vol. 8(2): 1-10.

Sarmila, M S; Zaimah, R; Rusyda, R; Novel, L; Rosniza, A C R; Sivapalan, S; Nur, H M; Nazirah, C J; Zaki, A and Mohd, K A I (2016). Sumbangan koperasi terhadap pembangunan komuniti pekebun kecil sawit: Kajian kes Koperasi Penanam Sawit Mampan (KPSM) Daerah Temerloh, Pahang dan Saratok, Sarawak. Prosiding Persidangan Kebangsaan Pekebun Kecil Sawit 2016. MPOB, Bangi. p. 117-133.

Standard Malaysia (2017). Audit Duration for Certification Bodies Operating Oil Palm Management Certification Under Malaysian Sustainable Palm Oil (MSPO) Certification Scheme (ACB-OPMC2), Issue 1. 1 August 2017. 6 pp.

Tomaquin, R D (2014). The impact of cooperatives as an economic and social institution in the fishing villages of Surigao del Sur (Philippines). American International J. Research in Humanities, Arts and Social Sciences, 5(1): 26-30.

United Nations (2013). Global Compact Sustainable Agriculture Business Principle. White Paper, July 2013. $30 \mathrm{pp}$. 